\title{
Genotype and Allele Frequency of CYP3A4 $-392 A>G$ in Turkish Patients with Major Depressive Disorder
}

\section{Majör Depresif Bozukluğu Olan Türk Hastalarında CYP3A4 -392A>G Genotip ve Allel Frekansı}

\author{
(D) Zuhal UÇKUN', (D) Bora BASKAK², (D) Hatice ÖZDEMIR², (D) Erguvan Tuğba ÖZEL-KIZIL², (D) Halise DEVRIMCi-ÖZGÜVEN², (D) Halit Sinan SÜZEN* \\ 'Mersin University, Faculty of Pharmacy, Department of Pharmaceutical Toxicology, Mersin, Turkey \\ ${ }^{2}$ Ankara University, Faculty of Medicine, Department of Psychiatry, Ankara, Turkey \\ ${ }^{3}$ Kırıkkale University, Faculty of Medicine, Department of Psychiatry, Kırıkkale, Turkey \\ ${ }^{4}$ Ankara University, Faculty of Pharmacy, Department of Toxicology, Ankara, Turkey
}

\section{ABSTRACT}

Objectives: Genetic polymorphisms may help for individualized drug dosing and improved therapeutics. CYP3A4 is responsible for the metabolism of more than $50 \%$ of the commonly used drugs and metabolizes typical antipsychotic medications and antidepressant drugs. The objective of the study was to assess the genotype and allele frequencies of CYP3A4 -392A>G in Turkish patients with major depressive disorder receiving any SSRIs and to compare these results with the frequencies of other ethnic groups.

Materials and Methods: Genotyping analyses of CYP3A4-392A>G was conducted on 84 Turkish patients using the PCR-RFLP technique.

Results: The allele frequencies were found as $0.982(A)$ and $0.018(G)$ for CYP3A4 -392A>G. The genotype frequencies were determined as 0.976 (AA), 0.012 (AG), and $0.012(G G)$. The genotype frequencies were consistent with the Hardy-Weinberg equilibrium.

Conclusion: The genotype and allele frequencies of CYP3A4-392A>G were determined to be low in Turkish patients with major depressive disorder receiving SSRIs. Furthermore, the results of the study were compared with those of other ethnic groups and they displayed pronounced differences among other ethnic groups, especially black subjects.

Key words: CYP3A4 -392A>G, polymorphism, Turkish patients, major depressive disorder

Öz

Amaç: Genetik polimorfizmler, bireyselleştirilmiş ilaç dozlaması ve geliştirilmiş terapötikler için yardımcı olabilir. CYP3A4 yaygın olarak kullanılan ilaçların \%50'sinden fazlasının metabolizmasından sorumludur ve tipik olarak antipsikotik ilaçlar, antidepresan ilaçları metabolize eder. Bu çalışmanın amacı, herhangi bir SSGi alan majör depresif bozukluğu olan Türk hastalarında CYP3A4 -392A>G'nin genotip ve alel frekanslarını değerlendirmek ve sonuçlarımızı diğer etnik gruplardaki frekanslarla karşılaştırmaktır.

Gereç ve Yöntemler: CYP3A4 -392A>G'nin genotiplendirme analizi, 84 Türk hastasında PZR-RFLP tekniği ile gerçekleștirilmiştir.

Bulgular: CYP3A4 -392A>G için allel frekanslarının 0.982 (A) ve 0.018 (G) olduğu saptanmıștır. Genotip frekanslarının ise 0.976 (AA), 0.012 (AG) ve 0.012 (GG) olduğu tespit edilmiştir. Genotip frekansları Hardy-Weinberg dengesiyle uyumludur.

Sonuç: CYP3A4 -392A>G'nin düşük frekansı, CYP3A4 ilaç metabolize edici enzimin SSGi'ler üzerinde oldukça düşük bir etkisinin olacağı önerilmektedir. Bunun yanı sıra, araștırmanın sonuçları diğer etnik gruplarla karşılaștırılmış olup etnik grup farklııklarının özellikle de siyah deneklerde belirlenmiștir.

Anahtar kelimeler: CYP3A4 -392A>G, polimorfizm, Türk hastalar, majör depresif bozukluk 


\section{INTRODUCTION}

Cytochrome P450 (CYP) is the major metabolizing enzymatic system in humans and CYP enzymes are responsible for the metabolism of exogenous compounds, including most clinically used drugs, mutagens, carcinogens, ${ }^{1,2}$ and some endogenous compounds, such as prostaglandins, steroids, vitamins, fatty acid derivatives and retinoic acid derivatives, and thromboxanes. ${ }^{2,3}$ CYP enzymes are responsible for the biotransformation of lipophilic compounds to polar metabolites, which can be excreted by the urine or bile. There are three major CYP families that encode enzymes that play an important role in phase I metabolism: CYP1, CYP2, and CYP3. ${ }^{3}$ The CYP3A subfamily is the most abundant CYP enzyme and represents about $30 \%$ of the total CYP in the human liver. ${ }^{2}$ Approximately $65 \%$ of current drugs used are metabolized by CYP enzymes and $45-60 \%$ of clinically administered drugs, and exogenous and endogenous compounds such as streoids, are metabolized by the CYP3A subfamily. 4.5 The CYP3A subfamily consists of 4 members: CYP3A4, CYP3A5, CYP3A7, and CYP3A43. ${ }^{5}$ The CYP3A4 enzyme is the most abundant CYP isoform in the liver and intestine, representing $60 \%$ and $70 \%$ of the total $\mathrm{P} 450$ amount, respectively. CYP $3 A 4$ is responsible for the metabolism of more than $50 \%$ of commonly prescribed drugs and metabolizes typical antipsychotic medications, antidepressant drugs (Table 1). ${ }^{6}$ Its interindividual hepatic expression varies 60 -fold, resulting in therapeutic failure, unpredictable adverse effects or severe drug toxicity.

The CYP3A4 gene is located on chromosome 7q21.3-q22.1, is 27,592 base pairs (bp) long, and has 13 exons.,8 Genetic polymorphisms of CYP3A4 were unknown until $1996 .{ }^{8}$ However, nowadays, CYP3A4 is known to be polymorphic, and more than 30 single nucleotide polymorphisms have been described in the CYP3A4 gene. The most common single-nucleotide polymorphism $-392 A>G$ in the promoter region of the CYP3A4 gene has been described. CYP3A4 -392A)G (rs2740574) is also known as CYP3A4*1B. It is known that the CYP3A4*1B polymorphism alters the transcription efficiency of the gene and hence the overall activity of CYP3A4.9

Selective serotonin reuptake inhibitors (SSRIs) are the firstline treatment for mild-to-severe major depressive disorder (MDD). ${ }^{10}$ The objective of this study was to assess the genotypic and allelic frequencies of the CYP3A4*1B in Turkish patients with MDD receiving SSRIs and to compare the results with frequencies in other ethnic groups.

\section{MATERIALS AND METHODS}

\section{Subjects}

The study was conducted on 84 Turkish patients with MDD at the Departments of Psychiatry, Schools of Medicine, Ankara University and Kırıkkale University, Turkey. All participants were administered with SSRIs. Approval for this study was obtained from the Ethics Committee of the Ankara University (21 April 2008, protocol no: 128-3581). The study was conducted in accordance with Good Clinical Practices and the Helsinki Declaration. All subjects gave their written informed consent to participate in this study. The demographic data of the patients with MDD are shown in Table 2.

\section{Blood sampling}

Blood samples $(10 \mathrm{~mL})$ were collected in vacutainer tubes containing EDTA as an anticoagulant between 08:00 and 09:00 a.m. at the $4^{\text {th }}$ and/or $6^{\text {th }}$ weeks of treatment. The Wizard Genomic DNA Purification Kit (Promega) was used to isolate genomic DNA from the cell fraction. DNA yields were determined by measuring the absorbance at $260 \mathrm{~nm}\left(\mathrm{~A}_{260}\right)$. All samples were stored at $-80^{\circ} \mathrm{C}$ until analysis.

\section{Genotyping}

The CYP3A4*1B (rs 2740574; -392A>G) polymorphism was identified using the polymerase chain reaction-restriction fragment length polymorphism (PCR-RFLP) method of Cavalli et al." with minor modifications. The primers employed were $\quad F:$ 5'-GGAATGAGGACAGCCATAGAGACAAGGGGA-3', R: 5'CCTTTCAGCTCTGTGT TGCTCTTTGCTG-3'. PCR was performed in a $25-\mu \mathrm{L}$ reaction mixture containig $300-500$ ng of genomic DNA, 10 pmol of each primer, $0.2 \mathrm{mM}$ each deoxynucleotidetriphosphate, $10 \times \mathrm{PCR}$ buffer, $1.5 \mathrm{mM} \mathrm{MgCl}$, and 1.25 unit of Taq polymerase (Fermentase) on the MBS Satellite Thermal Cycler (Thermo, UK). After initial denaturation for 5 min at $97^{\circ} \mathrm{C}, \mathrm{PCR}$ was performed for 30 cycles of $60 \mathrm{~s}$ at $95^{\circ} \mathrm{C}$, $90 \mathrm{~s}$ at $60^{\circ} \mathrm{C}, 60 \mathrm{~s}$ at $72^{\circ} \mathrm{C}$, and with a final step of $72^{\circ} \mathrm{C}$ for 10 min for elongation. No added DNA (negative control) reactions were included in each PCR analysis to ensure that the agents
Table 1. Common drugs metabolized by $C Y P 3 A 4^{6}$

Group of drugs

Antidepressants (SSRIs; SNRIs; tricyclics; others)

Antipsychotics (first generations; second generations)

Benzodiazepines

Opiates

Hypnotics

Antibiotics

Phosphodiesters inhibitors
Drug name

Citalopram, escitalopram, paroxetine, fluoxetine; venalafaxine, trazodone; amitriptyline, imipramine, clomipramine; buspirone nefazodone, mirtazapine

Haloperidol, perphenazine; aripiprazole, quetiapine, risperidone, ziprasidone

Alprazolam, diazepam, medazolam, temazepam, lorazepam, clonazepam

Codeine, methadone, fentanyl, buprenorphine

Zopiclone, zaleplon, zolpidem

Erythromycin, clarithromycin, telithromycin

Sildenafil, tadalafil 
contained no contaminating DNA. The PCR product (385 bp) was analyzed electrophoretically on a $2 \%$ agarose gel stained with ethidium bromide $(500 \mathrm{ng} / \mathrm{mL}$ ). Ten microliters of the PCR product were digested at $37^{\circ} \mathrm{C}$ overnight with $10 \mathrm{U}$ of $\mathrm{Mboll}$ with the appropriate buffer in a total volume of $20 \mu \mathrm{L}$. As shown in Figure 1, the digestion resulted in fragments of 175, 169, and 41 bp for the AA (wild type), and fragments of 210 and 175 bp for the GG (mutant). The digested fragments were electrophoresed on a $2 \%$ agarose gel and visualized using ethidium bromide.

\section{Table 2. Baseline characteristics of the patients with major} depressive disorder

\begin{tabular}{lll}
$\begin{array}{l}\text { Demographic and genotypic } \\
\text { characteristics }\end{array}$ & Mean \pm SD & Range (min-max) \\
\hline Body weight $(\mathrm{kg})$ & $70.12 \pm 14.39$ & $45.5-105$ \\
\hline BMl $\left(\mathrm{kg} / \mathrm{m}^{2}\right)$ & $25.94 \pm 5.14$ & $16.1-41.14$ \\
\hline & $\mathrm{n}$ & $\%$ \\
\hline Sex & & \\
\hline Female & 68 & 81 \\
\hline Male & 16 & 19 \\
\hline Age range & & \\
\hline$\leq 40$ & 53 & 63 \\
\hline$>40$ & 31 & 37 \\
\hline CYP3A4 gentypes &
\end{tabular}

CYP3A4 genotypes

Genotypic frequencies

\begin{tabular}{lll}
\hline$A A\left(\right.$ or $\left.{ }^{*} 1 A^{*} 1 A\right)$ & 82 & 97.6 \\
\hline$A G\left(\right.$ or $\left.{ }^{*} 1 A * 1 B\right)$ & 1 & 1.2 \\
\hline$G G\left(\right.$ or $\left.{ }^{*} 1 B^{*} 1 B\right)$ & 1 & 1.2
\end{tabular}

\begin{tabular}{lll}
\hline Allelic frequencies & & \\
\hline$A($ or $* 1 A)$ & 165 & 98.6 \\
\hline$G\left(\right.$ or $\left.{ }^{*} 1 B\right)$ & 3 & 1.8 \\
\hline
\end{tabular}

BMI: Body mass index

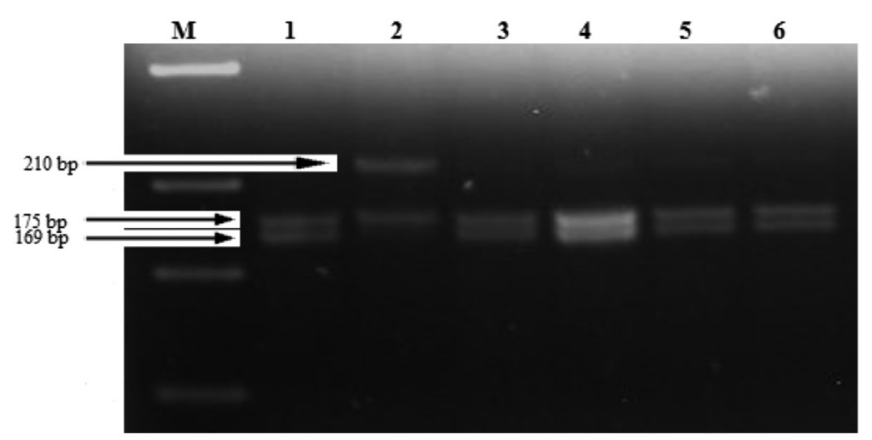

Figure 1. RFLP for the CYP3A4*1B polymorphism. Lane M: Marker, Lane 2: mutant (210, 175 bp), Lane 1,3-6: wild type (175, 169, 41 bp)

\section{Statistical analysis}

Genotype counting was used to calculate the allele and genotype frequencies. The observed and expected genotype frequencies of CYP3A4 were compared using the HardyWeinberg equilibrium. The comparison of the allele frequencies in the present investigation with those in other populations was made using the chi-square test. $P$ values $<0.05$ and $<0.001$ were considered statistically significant.

\section{RESULTS}

CYP $3 A 4^{*} 1 B(-392 A>G)$ polymorphism analysis was conducted on 84 Turkish patients with MDD. Of the 84 patients, $68(81 \%$ of patients) were female, whereas 16 (19\% of them) were male ( $p>0.05$ ) (Table 2). The body weight of the patients varied from 45.5 to $105 \mathrm{~kg}$, with a mean of $70.12 \pm 14.39 \mathrm{~kg}$. The body mass index (of the patients) ranged from 16.1 to $41.14 \mathrm{~kg} / \mathrm{m}^{2}$, with a mean of $25.94 \pm 5.14 \mathrm{~kg} / \mathrm{m}^{2}$. In the study, 53 subjects (63\%) were aged $\leq 40$ years, and 31 subjects ( $37 \%$ ) were aged $>40$ years.

The frequencies of the $A A, A G$, and $G G$ genotypes were 0.976 , 0.012 , and 0.012, respectively. According to these results, the frequencies of $A$ and $G$ alleles were 0.982 and 0.018 , respectively (Table 2 ). These results were consistent with the expected genotype frequencies of the Hardy-Weinberg equilibrium ( $p>0.05$ ).

\section{DISCUSSION}

Factors that can influence the response of a patient to any given drug depend on intrinsic (e.g., genetic and non-genetic factors such as sex, age, organ dysfunctions, disease state, and race/ ethnicity) and extrinsic factors (e.g., use of alcohol, smoking, diet, and concomitant medication).12,13 Genetics is estimated to account for 20 to $95 \%$ of variability in drug effects and disposition. ${ }^{14}$ It has been shown that much of this variability is produced by genetic polymorphisms of the CYP enzymes. ${ }^{4}$ CYP enzymes perform extensive structural differences because of genetic polymorphisms in the corresponding genes, and thus causing different enzymatic activities and giving rise to great intra- and inter-population variation in drug efficacy and adverse reactions. ${ }^{15}$

Approximately $65 \%$ of drugs in current use are metabolized by CYP enzymes, and $45-60 \%$ of clinically administered drugs, exogenous and endogenous compounds such as streoids, are metabolized by the CYP3A subfamily. ${ }^{4,5}$ CYP $3 A 4$ is a polymorphic enzyme, and its interindividual hepatic expression varies 60fold. ${ }^{7}$ CYP $3 A 4^{*} 1 B$, described as the most common variant, has been speculated to have reduced activity. ${ }^{16}$ Significant differences in allele frequencies of CYP3A variant occur among ethnic groups. ${ }^{16}$ Polymorphisms in human xenobiotic metabolizing genes show parallelism in ethnic, racial, and geographic distribution, and the ethnic-specific impact on CYP genes is known.

In this study, we aimed to investigate the CYP3A4*1B allele frequencies in Turkish patients with MDD receiving SSRIs and to compare the results with the frequencies of other ethnic groups. The allele frequencies in the Turkish population were 
Table 3. Allele frequencies of CYP3A4*1B in different ethnic populations

CYP3A4 allele frequencies

\begin{tabular}{|c|c|c|c|c|c|}
\hline Population & Healthy and control populations & $\mathrm{n}$ & $* 1 A$ & ${ }^{*} 1 B$ & References \\
\hline \multicolumn{6}{|l|}{ White } \\
\hline Turkish & Major depressive disorder & 84 & 0.982 & 0.018 & The present study \\
\hline Turkish & $\begin{array}{l}\text { Familial Mediterranean fever } \\
\text { patients }\end{array}$ & 46 & 0.967 & 0.033 & Dogruer et al. ${ }^{17}$ \\
\hline Turkish & $\begin{array}{l}\text { Children with lower urinary } \\
\text { tract symptoms }\end{array}$ & 34 & 0.956 & 0.044 & Gurocak et al..$^{18}$ \\
\hline Turkish & Healthy children & 42 & 0.939 & 0.061 & Gurocak et al. ${ }^{18}$ \\
\hline Caucasian (Germany) & Hospital controls & 428 & 0.972 & 0.028 & Dally et al. ${ }^{20}$ \\
\hline $\begin{array}{l}\text { Caucasian American } \\
\text { (Southern California) }\end{array}$ & Healthy & 117 & 0.961 & 0.039 & Paris et al. ${ }^{23}$ \\
\hline Finnish & Healthy & 118 & 0.958 & 0.042 & Sata et al. ${ }^{24}$ \\
\hline Spanish & Healthy & 163 & 0.957 & 0.043 & Gervasini et al. ${ }^{25}$ \\
\hline Portuguese & Control & 337 & 0.951 & 0.049 & Nogal et al. ${ }^{3}$ \\
\hline Dutch Caucasian & Healthy & 199 & 0.947 & 0.053 & van Schaik et al. ${ }^{26}$ \\
\hline Scottish & Healthy & 101 & 0.946 & 0.054 & Tayeb et al. ${ }^{27}$ \\
\hline \multicolumn{6}{|l|}{ Asians } \\
\hline Taiwanese & - & 130 & 1.000 & 0.000 & Walker et al. ${ }^{31}$ \\
\hline Japanese & Healthy & 128 & 1.000 & 0.000 & Ando et al..$^{32}$ \\
\hline Japanese & Healthy & 77 & 1.000 & 0.000 & Ball et al. ${ }^{33}$ \\
\hline Japanese & Hospital patients & 416 & 1.000 & 0.000 & Fukushima-Uesaka et al. ${ }^{34}$ \\
\hline Chinese & Healthy & 78 & 1.000 & 0.000 & Ball et al. ${ }^{33}$ \\
\hline Chinese & Healthy & 118 & 1.000 & 0.000 & Sata et al. ${ }^{24}$ \\
\hline Vietnamese & Healthy & 78 & 0.979 & 0.021 & Veiga et al. ${ }^{35}$ \\
\hline Jordanian & Healthy & 173 & 0.965 & 0.035 & Yousef et al. ${ }^{36}$ \\
\hline \multicolumn{6}{|l|}{ Black** } \\
\hline African-Brazilians & Healthy & 86 & 0.616 & 0.384 & Kohlrausch et al. ${ }^{30}$ \\
\hline African & Controls & 67 & 0.560 & 0.440 & McDaniel et al. ${ }^{37}$ \\
\hline African American & - & 70 & 0.470 & 0.530 & Walker et al. ${ }^{31}$ \\
\hline
\end{tabular}


Table 3. Continue

\begin{tabular}{|c|c|c|c|c|c|}
\hline African American & Healthy & 116 & 0.457 & 0.543 & Paris et al. ${ }^{23}$ \\
\hline African American & Healthy & 186 & 0.454 & 0.546 & Ball et al. ${ }^{33}$ \\
\hline African American & Controls & 103 & 0.427 & 0.573 & Bangsi et al. ${ }^{38}$ \\
\hline African American & Controls & 130 & 0.408 & 0.592 & Zeigler-Johnson et al. ${ }^{28}$ \\
\hline African & Healthy & 150 & 0.333 & 0.667 & Sata et al. ${ }^{24}$ \\
\hline Ghanaian & Healthy & 100 & 0.310 & 0.690 & Tayeb et al. ${ }^{27}$ \\
\hline African American & Healthy & 15 & 0.200 & 0.800 & Wandel et al. ${ }^{39}$ \\
\hline Ghanaian & Controls & 118 & 0.195 & 0.805 & Zeigler-Johnson et al. ${ }^{28}$ \\
\hline African & Healthy & 88 & 0.176 & 0.824 & Garsa et al. ${ }^{22}$ \\
\hline
\end{tabular}

Differences in allele frequencies were assessed by $\chi^{2}$ test. $n$ total number of subjects. Significant at ${ }^{*} p<0.05$ and ${ }^{* *} p<0.001$ when compared with the present study

0.982 and 0.018 for ${ }^{*} 1 A$ and ${ }^{*} 1 B$ alleles, respectively (Table 3). A comparison of the results of this investigation with the results of the other studies is presented in Table 3. Sayitoglu et al. ${ }^{16}$ reported that ${ }^{*} 1 B$ allele frequency was 0.014 in healthy Turkish subjects. Dogruer et al. ${ }^{17}$ reported that ${ }^{*} 1 B$ allele frequency was 0.033 in Turkish patients with familial Mediterranean fever. Gurocak et al. ${ }^{18}$ also reported that ${ }^{*} 1 B$ allele frequency was 0.044 and 0.061 for Turkish children with lower urinary tract symptoms and healthy Turkish children, respectively. The allele frequencies of these studies were not significantly different from the results of this study ( $p>0.05)$. However, when compared with black subjects, the allele frequency of Turkish subjects showed marked differences. The ${ }^{*} 1 B$ variant allele frequencies were identified more frequently in AfricanAmerican, African Brazilians, African, and Ghanaian individuals when compared with Turkish subjects ( $p$ <0.001). Furthermore, *1B variant allele frequencies were also reported to be higher in Caucasian American (Philadelphia), Saudi, EuropeanBrazilians, Hispanic populations when compared with Turkish populations $(p<0.05)$. The distribution of ${ }^{*} 1 A$ and ${ }^{*} 1 B$ alleles in Turkish populations was similar to those reported for Caucasians (Germany), Australian, European, Finnish, Spanish, Portuguese, Caucasians American (Southern California), Ducth Caucasian, and Scottish populations (Table 3).

The allelic frequency of CYP3A4*1B changes among different ethnic groups; CYP $3 A 4^{*} 1 B$ allelic frequency is dominant in black subjects with a range of 38.4 to $82.4 \%$ (Table 3 ). On the other hand, this polymorphism is very rare in Asian ethnic groups, including Vietnamese and Jordanian groups, ranging from 0 to $9.0 \%$. This polymorphism is absent in East Asian populations including the Japanese, Chinese, and Taiwanese, and present in White ethnic groups with a range of 1.8 to $14.3 \%$. Consequently, it seems that the CYP3A4*1B polymorphism is more frequent in White ethnic groups than in East Asian populations, and is more common in black subjects than in White ethnic groups. There is a minimal clinical effect of the CYP3A4*1B polymorphism on Asian ethnic groups. However, the $C Y P 3 A 4^{*} 1 B$ polymorphism seems to be more clinically important in black subjects.

\section{CONCLUSION}

The study introduces evidence of a low frequency of CYP $3 A 4^{*} 1 B$ allele in Turkish patients and compared this frequency with those of other ethnic groups. Given the effect of CYP3A4 on the efficacy of drugs, the genetic backgrounds of individuals and populations are accepted as a significant factor to be considered in the recipe of individualized medicine.19 Determining the expression of CYP3A4 may detect drug safety and efficacy and therefore help people to use the right dose of drugs..$^{15}$ CYP $3 A 4^{*} 1 B$ should be taken into consideration in populations where the allele frequency is high. On the other hand, a larger sample size would be needed to determine the CYP $3 A 4^{*} 1 B$ polymorphism in populations where the allele frequency is low.

\section{ACKNOWLEDGEMENTS}

This work was supported by the Scientific and Technological Research Council of Turkey (Project: 109S147).

Conflict of Interest: No conflict of interest was declared by the authors.

\section{REFERENCES}

1. Ota T, Kamada Y, Hayashida M, Iwao-Koizumi K, Murata S, Kinoshita K. Combination Analysis in Genetic Polymorphisms of Drug-Metabolizing Enzymes CYP1A2, CYP2C9, CYP2C19, CYP2D6 and CYP3A5 in the Japanese Population. Int J Med Sci. 2015;12:78-82.

2. Ruzilawati AB, Suhaimi AW, Gan SH. Genetic polymorphisms of CYP3A4: CYP3A4* 18 allele is found in five healthy Malaysian subjects. Clin Chim Acta. 2007;383:158-162.

3. Nogal A, Coelho A, Catarino R, Morais A, Lobo F, Medeiros R. The CYP3A4 *1B polymorphism and prostate cancer susceptibility in a Portuguese population. Cancer Genet Cytogenet. 2007;177:149-152.

4. Maruf AA, Ahmed MU, Azad MA, Ahmed M, Hasnat A. CYP3A genotypes in Bangladeshi tuberculosis patients. Bangladesh Med Res Counc Bull. 2012;38:1-5

5. Salameh G, Al Hadidi K, El Khateeb M. Genetic polymorphisms of the CYP3A4, CYP3A5, CYP3A7 and CYP1A2 among the Jordanian population. Environ Toxicol Pharmacol. 2012;34:23-33. 
6. Zhou Q, Yu X, Shu C, Cai Y, Gong W, Wang X, Wang DM, Hu S. Analysis of CYP3A4 genetic polymorphisms in Han Chinese. J Hum Genet. 2011;56:415-422.

7. Keshava C, Mccanlies EC, Weston A. CYP3A4 PolymorphismsPotential Risk Factors for Breast and Prostate Cancer: A HuGE Review. Am J Epidemiol. 2004;160:825-841.

8. Kumar V, Singh S, Yadav CS, Ahmed RS, Gupta S, Pasha ST, Tripathi AK, Banerjee BD. CYP1A1 and CYP3A4 polymorphic variations in Delhi population of Northern India. Environ Toxicol Pharmacol. 2010;29:126-130.

9. Ayano G. Psychotropic Medications Metabolized by Cytochromes P450 (CYP) 3A4 Enzyme and Relevant Drug Interactions: Review of Articles. Austin J Psychiatry Behav Sci. 2016;3:1-3.

10. Uckun Z, Baskak B, Ozdemir H, Ozel-Kizil ET, Devrimci Ozguven H, Suzen HS. Association Between the 5-HTTLPR Polymorphism and Response to Citalopram in Turkish Patients with Major Depressive Disorder. Turk J Pharm Sci. 2016;13:145-158.

11. Cavalli SA, Hirata MH, Hirata RD. Detection of Mboll polymorphism at the 5' promoter region of CYP3A4. Clin Chem. 2001;47:348-351.

12. Uckun Z, Baskak B, Ozel-Kizil ET, Ozdemir H, Devrimci Ozguven H, Suzen HS. The impact of CYP2C19 polymorphisms on citalopram metabolism in patients with major depressive disorder. J Clin Pharm Ther. 2015;40:672-679.

13. Huang SM, Goodsaid F, Rahman A, Frueh F, Lesko LJ. Application of Pharmacogenomics in Clinical Pharmacology. Toxicol Mech Methods. 2006;16:89-99.

14. Kerb R. Implications of genetic polymorphisms in drug transporters for pharmacotherapy. Cancer Lett. 2006;234:4-33.

15. Jin T, Yang $H$, Zhang J, Yunus Z, Sun Q, Geng T, Chen C, Yang J. Polymorphisms and phenotypic analysis of cytochrome P450 3A4 in the Uygur population in northwest China. Int J Clin Exp Pathol. 2015;8:7083-7091.

16. Sayitoglu MA, Yıldız I, Hatırnaz O, Ozbek U. Common Cytochrome p4503A (CYP3A4 and CYP3A5) and Thiopurine S-Methyl Transferase (TPMT) Polymorphisms In Turkish Population. Turk J Med Sci. 2006;36:11-15.

17. Dogruer D, Tug E, Bes C, Soy M. Lack of an effect of CYP3A4 and MDR1 gene polymorphisms on colchicine pharmacogenetics in the treatment of Familial Mediterranean fever. Genet Mol Res. 2013;12:3521-3528.

18. Gurocak S, Konac E, Ure I, Senol C, Onen IH, Sozen S, Menevse A. The Impact of Gene Polymorphisms on the Success of Anticholinergic Treatment in Children with Overactive Bladder. Dis Markers. 2015;2015:732686.

19. Lee JS, Cheong HS, Kim LH, Kim JO, Seo DW, Kim YH, Chung MW, Han SY, Shin HD. Screening of Genetic Polymorphisms of CYP3A4 and CYP3A5 Genes. Korean J Physiol Pharmacol. 2013;17:479-484.

20. Dally H, Bartsch H, Jäger B, Edler L, Schmezer P, Spiegelhalder B, Dienemann H, Drings P, Kayser K, Schulz V, Risch A. Genotype relationships in the CYP3A locus in Caucasians. Cancer Lett. 2004;207:95-99.

21. Spurdle AB, Goodwin B, Hodgson E, Hopper JL, Chen X, Purdie DM, McCredie MR, Giles GG, Chenevix-Trench G, Liddle C. The CYP3A4*1B polymorphism has no functional significance and is not associated with risk of breast or ovarian cancer. Pharmacogenetics. 2002;12:355-366.
22. Garsa AA, McLeod HL, Marsh S. CYP3A4 and CYP3A5 genotyping by Pyrosequencing. BMC Med Genet. 2005;6:19.

23. Paris PL, Kupelian PA, Hall JM, Williams TL, Levin H, Klein EA, Casey G, Witte JS. Association between a CYP3A4 Genetic Variant and Clinical Presentation in African-American Prostate Cancer Patients. Cancer Epidemiol Biomarkers Prev. 1999;8:901-905.

24. Sata F, Sapone A, Elizondo G, Stocker P, Miller VP, Zheng W, Raunio H, Crespi CL, Gonzalez FJ. CYP3A4 allelic variants with amino acid substitutions in exons 7 and 12: Evidence for an allelic variant with altered catalytic activity. Clin Pharmacol Ther. 2000;67:48-56.

25. Gervasini G, García-Martín E, Ladero JM, Pizarro R, Sastre J, Martínez C, García M, Diaz-Rubio M, Agúndez JA. Genetic variability in CYP3A4 and CYP3A5 in primary liver, gastric and colorectal cancer patients. BMC Cancer. 2007;7:118.

26. van Schaik RH, de Wildt SN, van Iperen NM, Uitterlinden AG, van den Anker JN, Lindemans J. CYP3A4-V Polymorphism Detection by PCRRestriction Fragment Length Polymorphism Analysis and Its Allelic Frequency among 199 Dutch Caucasians. Clin Chem. 2000;46:18341836.

27. Tayeb MT, Clark C, Ameyaw MM, Haites NE, Evans DA, Tariq M, Mobarek A, Ofori-Adjei D, McLeod HL. CYP3A4 promoter variant in Saudi, Ghanaian and Scottish Caucasian populations. Pharmacogenetics. 2000;10:753-756.

28. Zeigler-Johnson CM, Walker AH, Mancke B, Spangler E, Jalloh M, McBride S, Deitz A, Malkowicz SB, Ofori-Adjei D, Gueye SM, Rebbeck TR. Ethnic Differences in the Frequency of Prostate Cancer Susceptibility Alleles at SRD5A2 and CYP3A4. Hum Hered. 2002;54:13-21.

29. Rebbeck TR, Jaffe JM, Walker AH, Wein AJ, Malkowicz SB. Modification of Clinical Presentation of Prostate Tumors by a Novel Genetic Variant in CYP3A4. J Natl Cancer Inst. 1998;90:1225-1229.

30. Kohlrausch FB, Carracedo Á, Hutz MH. Characterization of CYP1A2, CYP2C19, CYP3A4 and CYP3A5 polymorphisms in South Brazilians. Mol Biol Rep. 2014:41:1453-1460.

31. Walker AH, Jaffe JM, Gunasegaram S, Cummings SA, Huang CS, Chern HD, Olopade OI, Weber BL, Rebbeck TR. Characterization of an allelic variant in the niphedipine-specific element of CYP3A4: Ethnic distribution and implications for prostate cancer risk. Mutation in Brief no. 191. Online. Hum Mutat. 1998;12:289.

32. Ando Y, Tateishi T, Sekido Y, Yamamoto T, Satoh T, Hasegawa Y, Kobayashi S, Katsumata Y, Shimokata K, Saito H. Re: Modification of clinical presentation of prostate tumors bya novel genetic variant in CYP3A4. J Natl Cancer Inst. 1999;91:1587-1590.

33. Ball SE, Scatina J, Kao J, Ferron GM, Fruncillo R, Mayer P, Weinryb I, Guida M, Hopkins PJ, Warner N, Hall J. Population distribution and effects on drug metabolism of a genetic variant in the $5^{\prime}$ promoter region of CYP3A4. Clin Pharmacol Ther. 1999;66:288-294.

34. Fukushima-Uesaka H, Saito Y, Watanabe H, Shiseki K, Saeki M, Nakamura T, Kurose K, Sai K, Komamura K, Ueno K, Kamakura S, Kitakaze M, Hanai S, Nakajima T, Matsumoto K, Saito H, Goto Y, Kimura H, Katoh M, Sugai K, Minami N, Shirao K, Tamura T, Yamamoto N, Minami H, Ohtsu A, Yoshida T, Saijo N, Kitamura Y, Kamatani N, Ozawa S, Sawada J. Haplotypes of CYP3A4 and Their Close Linkage With CYP3A5 Haplotypes in a Japanese Population. Hum Mutat. 2004;23:100. 
35. Veiga MI, Asimus S, Ferreira PE, Martins JP, Cavaco I, Ribeiro V, Hai TN, Petzold MG, Björkman A, Ashton M, Gil JP. Pharmacogenomics of CYP2A6, CYP2B6, CYP2C19, CYP2D6, CYP3A4, CYP3A5 and MDR1 in Vietnam. Eur J Clin Pharmacol. 2009;65:355-363.

36. Yousef AM, Bulatova NR, Newman W, Hakooz N, Ismail S, Qusa H, Zahran F, Anwar Ababneh N, Hasan F, Zaloom I, Khayat G, AlZmili R, Naffa R, Al-Diab O. Allele and genotype frequencies of the polymorphic cytochrome P450 genes (CYP1A1, CYP3A4, CYP3A5, CYP2C9 and (YP2C19) in the Jordanian population. Mol Biol Rep. 2012;39:9423-9433.

37. McDaniel DO, Thurber T, Lewis-Traylor A, Berry C, Barber WH, Zhou
X, Bigler S, Vance R. Differential association of cytochrome p450 3a4 genotypes with onsets of breast tumors in african american versus caucasian patients. J Investig Med. 2011;59:1096-1103.

38. Bangsi D, Zhou J, Sun Y, Patel NP, Darga LL, Heilbrun LK, Powell IJ, Severson RK, Everson RB. Impact of a genetic variant in CYP3A4 on risk and clinical presentation of prostate cancer among white and African-American men. Urol Oncol. 2006;24:21-27.

39. Wandel C, Witte JS, Hall JM, Stein CM, Wood AJ, Wilkinson GR. CYP3A activity in African American and European American men: Population differences and functional effect of the CYP3A $4{ }^{*} 1 \mathrm{~B} 55^{\prime}$-promoter region polymorphism. Clin Pharmacol Ther. 2000;68:82-91. 